\title{
ASPEK HUKUM TERHADAP PERSETUJUAN TINDAKAN MEDIK/KEDOKTERAN (INFORMED CONSENT) DALAM KAITANNYA DENGAN TINDAKAN TENAGA MEDIS DI RUMAH SAKIT Dr. TADJUDDIN CHALID MAKASSAR
} Sakir Sila Staf RS Dr. Tadjuddin Chalid Makassar Email: sila.sakir@yahoo.com

Abstract

Medical services as one of the elements of service that plays an important role in the provision of health services to patients In a professional relationship, there is an unequal or unequal position between the medical staff with the patient. Understanding of medical personnel (general practitioner and general dentist) at Dr. Hospital. Tadjuddin Chalid on informed consent still needs to be improved. Implementation of informed consent at Dr. Hospital. Tadjuddin Chalid Makassar has not been done well, this is because some medical personnel have not implemented Law no 29 of 2004 on Medical Practice.

Keyword: Medical Services, Informed Consent

\begin{abstract}
Abstrak
Pelayanan medis sebagai salah satu dari unsur pelayanan yang sangat berperan penting didalam pemberian pelayanan kesehatan kepada pasien Didalam hubungan profesional, maka terdapat suatu kedudukan yang tidak sama atau tidak seimbang antara tenaga medis dengan pihak pasien. Pemahaman tenaga medis (dokter umum dan dokter gigi umum) di Rumah Sakit Dr. Tadjuddin Chalid tentang informed consent masih perlu ditingkatkan. Pelaksanaan informed consent di Rumah Sakit Dr. Tadjuddin Chalid Makassar belumlah terlaksana dengan baik, hal ini disebabkan karena sebagian tenaga medis belum melaksanakan UndangUndang no 29 tahun 2004 tentang Praktik Kedokteran.
\end{abstract}

Kata Kunci: Pelayanan Medis, Informed Consent 


\section{LATAR BELAKANG}

embangunan di bidang kesehatan sebagai salah satu upaya
pembangunan nasional yang diarahkan guna tercapainya kesadaran,
kemauan dan kemampuan untuk hidup sehat bagi setiap penduduk agar
dapat mewujudkan derajat kesehatan yang optimal. Pembangunan kesehatan pada dasarnya menyangkut semua segi kehidupan baik fisik, mental maupun sosial. Dalam perkembangan pembangunan kesehatan selama ini, telah terjadi perubahan orientasi, baik dalam tata nilai maupun pemikiran terutama mengenai upaya pemecahan masalah dibidang kesehatan yang dipengaruhi oleh faktor-faktor politik, sosial, budaya, pertahanan dan keamanan serta ilmu pengetahuan dan teknologi. Perubahan orientasi tersebut akan mempengaruhi proses penyelenggaraan pembangunan kesehatan. Pembangunan kesehatan haruslah dilakukan secara komprehensif atau terpadu dan berkesinambungan guna mencapai hasil yang optimal. Pembangunan kesehatan itu meliputi peningkatan kesehatan atau promotif, pencegahan penyakit atau preventif, penyembuhan penyakit atau kuratif dan pemulihan kesehatan atau rehabilitatif.

Guna mencapai cita-cita tersebut di atas, maka tersedianya tenaga medis (dokter dan dokter gigi) yang handal dan memahami dengan baik hak dan kewajibannya adalah salah satu faktor penentu didalam tercapainya arah pembangunan kesehatan yang diharapkan. Hanya saja, didalam menjalankan profesi kedokteran atau kesehatan selama ini, ada satu hal yang jarang disadari oleh tenaga medis, bahwa saat ia menerima pasien untuk mengatasi masalah kesehatan baik penyembuhan penyakit (kuratif), pencegahan penyakit (preventif), pemulihan kesehatan (rehabilitatif), maupun peningkatan kesehatan (promotif), sebetulnya telah terjadi transaksi atau persetujuan antara dua pihak dalam bidang kesehatan.

Selama ini para tenaga medis memahami, bila mereka telah memiliki ijazah, maka mereka boleh praktek dan siap untuk memberikan pelayanan kesehatan sesuai dengan ijazah yang dimilikinya. Apalagi bila ia bertugas di rumah sakit, puskesmas atau di pusat pelayanan kesehatan lainnya, maka hanya ada satu dalam pemikirannya bahwa ia harus menjalankan profesinya sesuai dengan misi yang diemban atau ditugaskan. Tidak terlintas dalam pikirannya bahwa telah terjadi transaksi di bidang pengobatan (terapeutik).

Keadaan demikian dapat dipahami karena dahulu tidak pernah disampaikan dalam pendidikan bahwa menerima dan mengobati pasien adalah suatu persetujuan atau transaksi dibidang pengobatan yang mempunyai landasan hukum. Mungkin terasa aneh bila hubungan tenaga medis dengan pasien demikian disebut kontrak di bidang kesehatan, sebab pengertian kontrak selama ini lebih 
dekat pada pengertian sewa-menyewa, jual beli atau kontrak antara biro bangunan atau pemborong dengan masyarakat yang ingin membuat rumah atau bangunan lainnya.

Permasalahannya adalah dalam pelayanan medik, umumnya tenaga medis melihat pasien atau keluarganyalah yang datang meminta bantuan dan merupakan kewajiban tenaga medis untuk memberikan bantuan sesuai dengan kemampuannya. Tenaga medis tidak pernah membuat suatu perjanjian tertulis sebelum mengobati pasien, kecuali persetujuan yang diperlukan tenaga medis di rumah sakit sebelum melaksanakan tindakan bedah. Hal itulah yang kini harus diketahui dan dipahami oleh para tenaga medis, bahwa memang ada landasan hukum yang mengatur tentang hubungan antara dua pihak yang bersepakat untuk mencapai tujuan. Dalam bidang kesehatan hubungan ini terjalin dibidang jasa dan disebut sebagai transaksi terapeutik, persetujuan terapeutik atau kontrak terapeutik.

Mendudukkan hubungan tenaga medis dengan pasien yang mempunyai landasan hukum, dapat dimulai dengan pasal 1313 KUH Perdata : "Suatu perjanjian adalah suatu perbuatan dengan mana satu orang atau lebih mengikatkan dirinya terhadap satu orang atau lebih." Dengan demikian kedudukan pasien dan tenaga medis dalam pelayanan kesehatan seharusnya seimbang. Di satu sisi pasien membutuhkan tenaga medis untuk mengatasi masalah kesehatannya, sedangkan di lain pihak tenaga medis membutuhkan pasien untuk mendapatkan penghasilan sekaligus untuk mempraktekkan ilmu medis yang telah dipelajarinya di bangku pendidikan. Dengan kata lain, tanpa pasien ilmu para tenaga medis yang didapatkan di bangku kuliah tidak berguna sama sekali.

Masing-masing pihak, yaitu tenaga medis yang dalam posisi pemberi pelayanan ( medical providers) dan pasien sebagai penerima pelayanan ( medical receivers ) mempunyai hak dan kewajiban yang harus dihormati. Dalam ikatan demikianlah masalah informed consent atau Persetujuan Tindakan Medik/Kedokteran ini muncul. Di mana, seorang pasien atau keluarganya harus di berikan informasi atau penjelasan yang sejelas-jelasnya dari tenaga medis terhadap tindakan medik yang akan dilakukan terhadap diri si pasien, agar supaya memberikan persetujuan atau izin kepada tenaga medis tersebut. Dengan demikian akibat persetujuan itu akan terjadi " perjanjian " antara dua pihak. Kedua belah pihak bersetuju dan berjanji untuk melaksanakan sesuatu dalam bidang pengobatan atau kesehatan. Akibat perjanjian ini akan terjadi " perikatan " antara dua pihak yaitu pasien dan tenaga medis tersebut. 
Di dalam praktek terlihat bahwa hubungan antara tenaga medis dengan pasien masih sangat timpang yang mana tenaga medis masih memiliki posisi dominan sedangkan pasien hanya bersifat pasif menunggu dan terkesan pasrah terhadap apa yang akan dilakukan tenaga medis terhadapnya. Posisi demikian secara historis berlangsung selama bertahun-tahun. Tenaga medis memegang peranan utama, baik karena pengetahuan dan ketrampilan khusus yang dimiliki, maupun karena kewibawaan, yang dibawa olehnya karena merupakan bagian kecil masyarakat yang semenjak bertahun-tahun berkedudukan sebagai pihak yang memiliki otoritas di dalam memberikan bantuan pengobatan berdasarkan kepercayaan penuh pasien. Sudah menjadi pengetahuan umum bahwa tenaga medis sangat jarang meminta persetujuan dari pasien apabila ingin melaksanakan rangkaian upaya penyembuhan pasien, kecuali dalam hal tindakan pembedahan dan tindakan yang mempunyai resiko medis yang sangat tinggi. Persetujuan itupun juga diminta oleh tenaga medis tanpa penjelasan yang sejelas-jelasnya dan kadang kala ada yang terkesan dipaksakan, apalagi kalau pasien tersebut berobat dengan memakai kartu Jaminan Kesehatan Masyarakat Miskin atau sejenisnya.

Padahal di Indonesia ketentuan tentang informed consent sudah diatur di dalam pasal 45 Undang-undang No 29 Tahun 2004 tentang Praktik Kedokteran yang menyatakan sebagai berikut :

1. Setiap tindakan kedokteran atau kedokteran gigi yang akan dilakukan oleh dokter atau dokter gigi terhadap pasien harus mendapat persetujuan.

2. Persetujuan sebagaimana dimaksud ayat (1) diberikan setelah pasien mendapat penjelasan secara lengkap.

3. Penjelasan sebagaimana dimaksud pada ayat (2) sekurang-kurangnya mencakup :

a. Diagnosis dan tata cara tindakan medis;

b. Tujuan tindakan medis yang dilakukan;

c. Alternatif tindakan lain dan resikonya;

d. Risiko dan komplikasi yang mungkin terjadi; dan

e. Prognosis terhadap tindakan yang dilakukan.

4. Persetujuan sebagaimana dimaksud ayat (2) dapat diberikan baik secara tertulis maupun lisan.

5. Setiap tindakan kedokteran atau kedokteran gigi yang mengandung risiko tinggi harus diberikan dengan persetujuan tertulis yang ditanda tangani oleh yang berhak memberikan persetujuan.

6. Ketentuan mengenai tata cara persetujuan tindakan kedokteran atau kedokteran gigi sebagaimana dimaksud pada ayat (1), ayat (2), ayat (3), ayat (4), dan ayat (5) di atur dengan Peraturan Menteri. 
Ketentuan lebih dahulu tentang hal-hal yang berhubungan dengan informed consent atau Persetujuan Tindakan Medik/Kedokteran diatur di dalam Peraturan Menteri Kesehatan Republik Indonesia Nomor 585/Men.Kes/Per/IX/1989 tentang Persetujuan Tindakan Medik yang kemudian diganti dengan Peraturan Menteri Kesehatan Nomor 290/Men.Kes/Per/III/2008 tentang Persetujuan Tindakan Kedokteran.

Sesuai ketentuan di atas, jelaslah bahwa di dalam menentukan pengobatan terhadap diri pasien, tenaga medis harus meminta persetujuan baik lisan atau tertulis, tergantung dari berat-ringannya risiko yang akan dihadapi si pasien dan tenaga medis di dalam melakukan tindakan pengobatan. Oleh karena di dalam pasal 52 huruf a dan d Undang-undang Praktik Kedokteran dijelaskan bahwa : pasien, dalam menerima pelayanan pada praktik kedokteran, mempunyai hak mendapatkan penjelasan secara lengkap tentang tindakan medis sebagaimana di maksud dalam pasal 45 ayat (3) dan di samping itu pula pasien berhak menolak tindakan medik. Oleh karena itu, informed consent atau Persetujuan Tindakan Medik/Kedokteran merupakan keharusan bagi tenaga medik di dalam merencanakan upaya pengobatan terhadap pasien.

\section{METODE PENELITIAN}

Penelitian ini termasuk penelitian hukum normatif-empiris, yaitu penelitian hukum yang objek kajiannya meliputi ketentuan perundang-undangan serta penerapannya pada peristiwa hukum. Penelitian ini akan dilakukan di Rumah Sakit Dr. Tadjuddin Chalid Makassar.

Data yang digunakan berupa data primer dan sekunder. Data primer diperoleh secara langsung dari responden yang dikumpulkan melalui wawancara dan angket kepada pihak yang berhubungan dengan objek penelitian. Adapun data sekunder yang diperoleh dari berbagai literatur berupa buku-buku, peraturan perundang-undangan serta dokumen yang terkait dengan objek penelitian ini.

Metode analisis dalam penulisan ini dengan mengumpulkan dan menganalisis data secara kualitatif dan kuantitatif. Analisis kualitatif dipergunakan terhadap data yang bersumber dari wawancara, sedangkan analisis kuantitatif dilakukan pada data yang didapatkan dari hasil angket dengan memakai rumus :

$$
\begin{aligned}
& \mathrm{P}=\mathrm{f} / \mathrm{n} \times 100 \% \\
& \text { Keterangan }: \\
& \mathrm{P}=\text { Prosentasi } \\
& \mathrm{f}=\text { frekwensi } \\
& \mathrm{n}=\text { nilai }
\end{aligned}
$$




\section{PEMBAHASAN DAN HASIL PENELITIAN}

\section{A. Pemahaman Para Tenaga Medis di Rumah Sakit Dr. Tadjuddin Chalid Makassar tentang Informed Consent ditinjau dari segi hukum}

Pelayanan medis sebagai salah satu dari unsur pelayanan yang sangat berperan penting didalam pemberian pelayanan kesehatan kepada pasien. Di dalam pelayanan medis itu terdapat para tenaga medis sebagai pemberi pelayanan (medical providers) dan pasien sebagai penerima pelayanan (medical receivers). Masing-masing pihak mempunyai hak dan kewajiban yang harus dihormati. Didalam pelaksanaan profesinya, tenaga medis harus berlaku jujur dan menjaga agar pasien tidak sampai dirugikan karenanya, disamping itu tenaga medis juga harus mengetahui hal-hal yang berhubungan dengan informed consent sebagai dasar atau persetujuan (izin) bagi tenaga medis didalam memberikan tindakan medik kepada pasien.

Dalam rangka mendalami pemahaman tenaga medis tentang informed consent penulis mengambil sampel penelitian dari kalangan dokter (umum) dan dokter gigi (umum) di Rumah Sakit Dr. Tadjuddin Chalid Makassar dengan alasan mereka inilah yang mempunyai jumlah mayoritas dan juga melakukan pelayanan medik kepada pasien dengan intensitas yang paling sering. Oleh karena itu penulis menyebarkan angket kepada 19 orang tenaga medis dari kalangan dokter (umum) dan dokter gigi (umum) dari keseluruhan 26 orang tenaga dokter (umum) dan dokter gigi (umum) fungsional yang masih aktif bekerja di Rumah Sakit Dr. Tadjuddin Chalid Makassar (data diambil tanggal 8 Agustus 2009 dari Bagian Medis Rumah Sakit Dr. Tadjuddin Chalid Makassar). Disamping itu, juga melakukan wawancara kepada beberapa orang pasien yang sedang di rawat di Rumah Sakit Dr. Tadjuddin Chalid Makassar. Dari 19 orang responden yang diberikan angket, semuanya memahami dengan sangat baik defenisi dari informed consent. Hal ini dapat diperhatikan pada tabel dibawah ini :

Tabel 1

Pemahaman Tenaga Medis Mengenai Defenisi Informed Consent

\begin{tabular}{|c|c|c|c|}
\hline No & Defenisi Informed Consent adalah & $\mathrm{F}$ & $\%$ \\
\hline 2. & $\begin{array}{l}\text { Persetujuan yang diberikan pasien/keluarga terhadap } \\
\text { rencana tindakan medik yang akan dilakukan padanya } \\
\text { setelah diberikan penjelasan } \\
\text { Penandatanganan formulir persetujuan oleh pasien }\end{array}$ & 19 & 100 \\
\hline \multicolumn{2}{|c|}{ Jumlah } & 19 & 100 \\
\hline
\end{tabular}

Sumber : Diolah dari angket Agustus 2009 
Data di atas memperlihatkan bahwa semua responden (100\%) mengerti bahwa informed consent adalah suatu persetujuan yang diberikan oleh pasien atau keluarga terdekatnya kepada tenaga medis untuk melakukan tindakan medik/kedokteran setelah pasien mendapatkan penjelasan yang selengkapnya dari tenaga medis tentang penyakitnya dan resiko tindakan yang akan diberikan. Ini berarti bahwa tenaga medis telah memahami dengan baik dasar-dasar pentingnya informed consent dalam memberikan pelayanan kepada pasien. Hanya saja, pada pemahaman tentang unsur terpenting di dalam informed consent mulai terdapat perbedaan persepsi, yaitu terdapat 12 orang $(63,2 \%)$ responden berpendapat bahwa unsur terpenting dalam informed consent adalah proses komunikasi yang baik antara tenaga medis dengan pasien untuk bersama-sama menentukan pilihan tindakan yang terbaik buat pasien, 3 orang $(15,8 \%)$ responden menganggap penandatanganan formulir persetujuan oleh pasien/keluarganyalah yang penting, adapula 4 orang $(21 \%)$ responden yang berprinsip bahwa pemberian persetujuan oleh pasien/keluarganyalah yang terpenting walaupun tidak melalui proses komunikasi yang baik. Lebih jelasnya perhatikan tabel berikut ini :

Tabel 2

Unsur Terpenting Dalam Informed Consent

\begin{tabular}{|c|l|c|c|}
\hline No & \multicolumn{1}{|c|}{ Unsur terpenting dalam informed consent } & F & $\%$ \\
\hline 1. & Proses komunikasi yang baik & 12 & 63,2 \\
2. & Penandatanganan formulir & 3 & 15,8 \\
3. & Pemberian persetujuan & 4 & 21 \\
\hline \multicolumn{2}{|l|}{ Jumlah } & 19 & 100 \\
\hline
\end{tabular}

Sumber : Diolah dari angket Agustus 2009

Data ini menggambarkan bahwa masih ada sebagian tenaga medis ( 7 orang atau 3,8 \%), yang belum memahami bahwa proses komunikasi yang baik dengan pasien sebelum melakukan tindakan medik adalah merupakan unsur yang terpenting di dalam informed consent, bukan mengutamakan penandatanganan suatu formulir saja atau hanya mendapatkan suatu persetujuan dari pasien tanpa memberikan penjelasan yang sejelas-sejelasnya kepada pasien atau keluarganya terhadap tindakan medik yang akan dilakukan terhadap diri pasien.

Pemberian informasi kepada pasien sebelum melakukan tindakan medik wajib dilakukan tenaga medis, sebagai perwujudan penghargaan terhadap hak asasi manusia dari tenaga medis terhadap pasien dalam mendapatkan informasi yang diperlukan demi kesembuhan sipasien. Oleh sebab itu penjelasan tentang diagnosis dan tata cara tindakan medik/kedokteran, tujuan tindakan medik/kedokteran yang akan dilakukan, alternatif tindakan lain dan risikonya, 
risiko dan komplikasi yang mungkin terjadi, prognosis terhadap tindakan yang dilakukan, dan perkiraan pembiayaan merupakan keseluruhan hal-hal yang harus dijelaskan oleh tenaga medis. Siapakah yang paling bertanggung jawab terhadap pemberian informasi tentang tindakan medik yang akan dilakukan ?. Perhatikan tabel berikut :

Tabel 3

Pihak yang Paling Bertanggung Jawab Terhadap Pemberian Informasi

\begin{tabular}{|c|l|c|c|}
\hline No & \multicolumn{1}{|c|}{ Yang bertanggung jawab memberi informasi } & F & $\%$ \\
\hline 1. & Tenaga medis yang langsung menangani pasien & 16 & 84,2 \\
2. & Tenaga medis dan perawat & 2 & 10,5 \\
3. & Pihak Rumah Sakit & 1 & 5,3 \\
\hline \multicolumn{2}{|l}{ Jumlah } & 19 & 100 \\
\hline
\end{tabular}

Sumber : Diolah dari angket Agustus 2009

Tabel diatas memperlihatkan bahwa sebagian besar responden (16 orang atau $84,2 \%$ ) telah memahami bahwa tenaga medis yang langsung menangani pasienlah yang paling bertanggung jawab memberikan informasi, karena dialah yang paling mengetahui hal-hal yang berhubungan dengan tindakan yang akan dilakukannya serta hal-hal yang dibutuhkan pasien di dalam penyembuhan sakitnya, bukan tenaga kesehatan lain atau pihak Rumah Sakit. Tetapi masih ada juga 2 orang $(10,5 \%)$ menganggap tenaga medis dan perawatlah yang harus bertanggung jawab, disamping itu ada 1 orang $(5,3 \%)$ mengemukakan bahwa pihak Rumah Sakit tempatnya bekerja si tenaga medislah yang harus menjelaskan tindakan medik yang akan dilakukan. Fakta ini diperkuat oleh pengakuan Ibu Sadariah salah seorang pasien di bangzal perempuan Rumah Sakit Dr. Tadjuddin Chalid Makassar (wawancara, 8 Agustus 2009), menyatakan :

Pada saat melakukan pemeriksaan, dokter (tenaga medis)lah yang memberikan penjelasan tentang tujuan dan segala hal-hal yang berhubungan dengan pemeriksaan yang dilakukan, begitupun juga pada saat dokter (tenaga medis) tersebut memberi obat kepada saya, tidak lupa diberikan penjelasan tentang jenis obatnya, kegunaannya, cara pemakaiannya dan reaksi yang timbul setelah pemakaian obat tersebut.

Pengakuan Ibu Sadariah di atas kontradiksi dengan penuturan Bapak Lasude yang juga salah seorang pasien di Rumah Sakit Dr. Tadjuddin Chalid Makassar (wawancara, 8 Agustus 2009), mengatakan bahwa :

Dokter (tenaga medis) jarang memberikan penjelasan pada saat mengobati pasien, penjelasan diberikan apabila ditanyakan oleh pasien dan penjelasan 
itu biasa diberikan oleh dokter atau perawat yang bertugas merawat pasien.

Rambu-rambu tentang siapa yang paling bertanggung jawab memberikan penjelasan terhadap tindakan medik yang akan dilakukan telah diatur dalam peraturan perundang-undangan. Penjelasan tentang tindakan medik yang akan dilakukan diberikan oleh tenaga medis yang merawat pasien atau salah satu tenaga medis dari tim yang merawatnya, dalam hal tenaga medis yang merawatnya berhalangan untuk memberikan penjelasan secara langsung maka pemberian penjelasan harus didelegasikan kepada tenaga medis lain yang kompeten, tenaga kesehatan tertentu dapat membantu memberikan penjelasan sesuai dengan kewenangannya (pasal 10 PerMenKes no 290 tahun 2008).

Pasal 10 PerMenkes no 290 tahun 2008 diatas, dengan tegas memberikan pedoman bahwa pihak yang paling bertanggung jawab memberikan penjelasan terhadap hal-hal yang berhubungan dengan tindakan medik yang akan dilakukan, berada di pundak tenaga medis atau tim tenaga medis yang menangani/merawat langsung pasien, tenaga medis yang lain yang kompeten hanya bisa menjelaskan apabila di delegasikan oleh tenaga medis yang langsung merawat pasien kepadanya, perawat atau tenaga kesehatan lain hanya sekedar membantu menjelaskan sesuai dengan kemampuan atau kewenangan yang dimilikinya, sedangkan pihak Rumah Sakit sama sekali tidak mempunyai kewajiban untuk memberikan penjelasan terhadap tindakan medik yang akan dilakukan kepada pasien.

Pada saat memeriksa awal pasien termasuk melakukan pemeriksaan laboratorium, rontgen dan semua pemeriksaan yang tidak beresiko tinggi dan kemudian setelah itu memberikan obat (oral, suntikan, zalf dsbnya) tenaga medis wajib meminta/mendapatkan persetujuan dari pasien atau keluarga terdekatnya. Hal ini sebagai salah satu syarat sah atau tidaknya suatu informed consent. Coba perhatikan tabel berikut ini :

Tabel 4

Permintaan Persetujuan pada Pemeriksaan Awal dan Memberikan Obat

\begin{tabular}{|c|l|c|c|}
\hline No & \multicolumn{1}{|c|}{ Meminta/diberikan persetujuan oleh pasien } & $\mathrm{F}$ & $\%$ \\
\hline 1. & Ya & 14 & 73,7 \\
2. & Tidak & 5 & 26,3 \\
& & & \\
\hline \multicolumn{2}{|c|}{ Jumlah } & 19 & 100 \\
\hline
\end{tabular}

Sumber : Diolah dari angket Agustus 2009 
Tabel di atas menggambarkan bahwa ada 14 orang $(73,7 \%)$ responden yang mengemukakan bahwa mereka meminta persetujuan pasien atau keluarga terdekatnya pada saat akan melakukan pemeriksaan awal atau pemeriksaan laboratorium, rontgen dsbnya, termasuk juga pada saat memberikan obat oral, zalf, suntikan dsbnya. Tetapi ada pula 5 orang $(26,3 \%)$ responden yang mengatakan bahwa mereka tidak meminta persetujuan pada saat melakukan pemeriksaan dan memberikan obat. Hal ini bertentangan dengan penuturan Bapak Baddu Asis salah seorang pasien (Wawancara, 9 Agustus 2009) mengemukakan :

Dokter (tenaga medis) pada saat melakukan pemeriksaan awal di poliklinik seperti pemeriksaan laboratorium, roentgen dsbnya, tidak pernah meminta persetujuan dari pasien tetapi langsung saja memberikan surat pengantar untuk melakukan pemeriksaan.

Situasi ini menegaskan kalau ada persepsi yang berbeda antara tenaga medis dengan pasien. Menurut hemat penulis, seperti penjelasan pada Bab 2 mungkin saja tenaga medis menganggap telah mendapatkan persetujuan secara tersirat (dianggap diberikan) atau biasa disebut implied consent dari pasien di dalam memberikan tindakan medik kepada dirinya. Karena sudah menjadi pengetahuan umum bahwa pemeriksaan standar atau pengobatan standar seperti diatas itu, umum diberikan/dilakukan tenaga medis apabila pasien datang berobat kepadanya. Disamping itu, selain harus mendapatkan persetujuan dari pasien atau keluarganya, tenaga medis juga wajib menjelaskan tentang diagnosa penyakit, tujuan pemeriksaan yang akan/sudah dilakukan, kegunaan obat dan cara pemakaiannya, reaksi obat, risiko tindakan yang dilakukan, ramalan penyakitnya dan semua hal-hal yang berhubungan dengan penyakit pasien. Untuk menjawab apakah tenaga medis di Rumah Sakit Dr. Tadjuddin Chalid telah melaksanakan hal tersebut diatas lihat tabel berikut :

Tabel 5

Penjelasan Tenaga Medis tentang Diagnosa Penyakit, Tujuan Pemeriksaan, Kegunaan Obat dan Cara Pemakaiannya, Reaksi Obat dan Segala Hal-Hal yang Berhubungan dengan Penyakit Pasien

\begin{tabular}{|c|l|c|c|}
\hline No & \multicolumn{1}{|c|}{ Pemberian penjelasan } & F & $\%$ \\
\hline 1. & Memberikan penjelasan & 16 & 84,2 \\
2. & Tidak memberikan penjelasan & 0 & 0 \\
3. & Kadang-kadang memberikan penjelasan & 3 & 15,8 \\
\hline \multicolumn{2}{|l|}{ Jumlah } & 19 & 100 \\
\hline
\end{tabular}

Sumber : Diolah dari angket Agustus 2009 
Data di atas melukiskan bahwa 16 orang (84,2 \%) responden mengemukakan bahwa tenaga medis haruslah memberikan penjelasan pada waktu melakukan pemeriksaan terhadap pasien atau memberikan pengobatan yang terdiri dari diagnosa penyakit, tujuan pemeriksaan (laboratorium, rontgen dsbnya), kegunaan obat dan cara pemakaiannya, reaksi obatnya, risiko tindakan yang dilakukan, ramalan penyakit dsbnya. Sementara itu 3 orang $(15,8 \%)$ responden mengatakan bahwa mereka hanya kadang-kadang memberikan penjelasan artinya biasa mereka memberi penjelasan sesuai dengan kebutuhan dan kondisi pasien, kadang juga mereka tidak sempat memberikan penjelasan karena terlalu banyak pasien yang dilayani atau karena mereka menganggap pasien sudah tahu tentang hal-hal yang berhubungan dengan pemeriksaan dan pengobatan yang dilakukan.

Pendapat yang berbeda disampaikan oleh Bapak Iswadi, salah seorang pasien di Bangzal F Rumah Sakit Dr. Tadjuddin Chalid Makassar (wawancara, 10 Agustus 2008) bahwa :

Pada saat melakukan pemeriksaan dan memberikan obat, dokter (tenaga medis) tidak memberikan penjelasan tentang kegunaan dan hal-hal yang berhubungan dengan pemeriksaan maupun pengobatan.

Menyangkut hal tersebut di atas, didalam pasal 45 ayat 3 Undang-undang no 29 tahun 2004 tentang Praktik Kedokteran jo pasal 7 ayat 3 PerMenKes no 290 tahun 2008 tentang Persetujuan Tindakan Kedokteran mengemukakan bahwa penjelasan tentang tindakan kedokteran sekurang-kurangnya mencakup :

a. diagnosis dan tata cara tindakan kedokteran

b. tujuan tindakan kedokteran yang dilakukan

c. alternatif tindakan lain dan risikonya

d. Risiko dan komplikasi yang mungkin terjadi, dan

e. Prognosis terhadap tindakan yang dilakukan,

f. Perkiraan pembiayaan.

Berdasarkan aturan diatas, jelaslah kalau tenaga medis mempunyai kewajiban memberikan penjelasan kepada pasien atau keluarga terdekatnya tentang hal-hal tersebut diatas apabila ingin melakukan suatu tindakan medik. Ini sebagai wujud penghormatan terhadap hak asasi pasien, Disamping itu juga menghindari terjadinya gugatan dari pasien apabila terjadi kerugian yang terjadi pada pihaknya akibat tindakan yang dilakukan oleh tenaga medis.

Di dalam melayani pasien seorang tenaga medis kadang harus meminta persetujuan (informed consent) dari pasien atau keluarga terdekatnya dengan cara tertulis. Ini dilakukan tenaga medis apabila berhubungan dengan hal-hal yang bisa membahayakan kedudukan/posisi tenaga medis. Sebagaimana telah disebutkan pada Bab 2 bahwa tenaga medis didalam memberikan pelayanan kesehatan adalah 
pada umumnya merupakan inspanningverbintenis. Yaitu secara hati-hati dan teliti tenaga medis berusaha mempergunakan ilmu, kepandaian, keterampilan, dan pengalamannya untuk menyembuhkan pasien. Hasil usaha yang dilakukan tenaga medis tidaklah pasti, ada kemungkinan pasien sembuh, tetap sakit, tambah sakit, atau bahkan mati. Tenaga medis tidak dapat menjamin hasil usaha yang dilakukannya dalam memberikan pelayanan kesehatan, oleh sebab itu untuk menghindari hal-hal yang tidak diinginkan maka peraturan perundang-undangan telah memberikan pedoman yang jelas kepada tenaga medis didalam bertindak apabila melayani pasien di dalam memberikan tindakan medik yang beresiko tinggi dsbnya. Oleh sebab itu tenaga medis seharusnya meminta persetujuan tertulis apabila akan melakukan tindakan medik yang mengandung resiko tinggi terhadap kehidupan pasien ataupun membahayakan bagi sitenaga medis dari segi hukum. Untuk mengetahui pemahaman tenaga medis tentang pada tindakan apa saja yang dibutuhkan informed consent yang tertulis, simak tabel berikut :

Tabel 6

Pemahaman Tenaga Medis tentang Tindakan Apa Sajakah Dibutuhkan Informed Consent yang tertulis

\begin{tabular}{|c|c|c|c|}
\hline No & Informed consent tertulis dibutuhkan pada & $\mathrm{F}$ & $\%$ \\
\hline 1. & Tindakan medik/kedokteran kompleks atau berisiko & 13 & 68,4 \\
\hline 2. & Tindakan medik/kedokteran bukan dalam rangka terapi & 0 & 0 \\
\hline 3. & Tindakan yang berdampak bagi kedudukan & & \\
\hline & kepegawaian, pribadi dan sosial pasien & 0 & 0 \\
\hline 4. & Tindakan yang bagian dari suatu penelitian & 0 & 0 \\
\hline 5. & Semuanya & 6 & 31,6 \\
\hline \multicolumn{2}{|r|}{ Jumlah } & 19 & 100 \\
\hline
\end{tabular}

Sumber : Diolah dari angket Agustus 2009

Dari hal di atas dapat terbaca kalau ada 13 orang $(68,4 \%)$ responden berpendapat untuk menghindari pelanggaran hukum, persetujuan tertulis dari pasien dibutuhkan hanya pada saat tenaga medis ingin melakukan tindakan terapeutik yang bersifat kompleks atau menyangkut risiko atau efek samping yang bermakna. Ada 6 orang $(31,6)$ responden menganggap bahwa persetujuan tertulis dibutuhkan tidak saja pada tindakan medik yang bersifat kompleks atau menyangkut risiko tetapi informed consent yang tertulis dibutuhkan juga pada tindakan medik yang bukan terapi, tindakan medik yang memiliki dampak bagi kedudukan kepegawaian atau kehidupan pribadi dan sosial serta tindakan yang merupakan bagian dari suatu penelitian. 
Fakta di atas menggambarkan bahwa mayoritas responden (13 orang atau $68,4 \%$ ) belum mengetahui kalau semua tindakan medik yang tercantum pada pertanyaan dalam tabel 6 di atas, haruslah mendapatkan informed consent secara tertulis karena mengandung resiko yang besar baik bagi sipasien (dampak sosial, ekonomi, cacat fisik/psikhis maupun kematian) maupun bagi tenaga medis (gugatan dari pihak pasien), disamping itu pula adalah sebagai penghargaan terhadap hak asasi manusia, agar supaya sipasien tidak dijadikan sebagai kelinci percobaan oleh tenaga medis atau mahasiswa kedokteran didalam mempraktekkan ilmu atau teori yang didapatkannya di bangku kuliah. Aturan ini secara tegas tercantum didalam manual persetujuan tindakan kedokteran yang disusun oleh Konsil Kedokteran Indonesia (2006), yang berbunyi :

Persetujuan tertulis diperlukan pada :

a. Bila tindakan terapeutik bersifat kompleks atau menyangkut risiko atau efek samping yang bermakna;

b. Bila tindakan kedokteran tersebut bukan dalam rangka terapi;

c. Bila tindakan kedokteran tersebut memiliki dampak yang bermakna bagi kedudukan kepegawaian atau kehidupan pribadi dan sosial pasien; dan

d. Bila tindakan yang dilakukan adalah bagian dari suatu penelitian.

\section{B. Pelaksanaan Informed Consent Di Rumah Sakit Dr. Tadjuddin Chalid Makassar Sesuai Dengan Peraturan Perundang-Undangan Yang Berlaku}

Responden yang diberikan angket yaitu sebanyak 40 orang dari 103 orang jumlah keseluruhan pasien Kusta yang dirawat nginap di Rumah Sakit Dr. Tadjuddin Chalid Makassar (data diambil pada tanggal 8 Agustus 2009 dari Instalasi Rawat Nginap Rumah Sakit Dr. Tadjuddin Chalid Makassar), atau dengan perbandingan 38,8 \% dari jumlah populasi yang ada, dan semuanya menggunakan Kartu Jaminan Kesehatan Masyarakat Miskin atau sejenisnya. Disamping itu dilakukan wawancara dengan Dr. Aditia Akram (Kepala Bidang Medis), Dr. Ilyas Rahim (Dokter senior) dan pasien atas nama Ibu Nurhayati.

\section{Alasan utama Pasien Melakukan Perjanjian Terapeutik dan Melakukan Informed Consent.}

Saat pasien datang ke sarana pelayanan kesehatan maka dengan otomatis pasien sudah memahami bahwa ia akan mendapatkan pelayanan dari tenaga kesehatan (tenaga medis) atau dengan kata lain akan melakukan perjanjian terapeutik. Begitupun pasien yang datang berobat di Rumah Sakit Dr. Tadjuddin Chalid Makassar. Hanya saja apakah pasien melakukannya dengan sukarela 
ataukah karena alasan lain?. Sudah umum masyarakat tahu bahwa alasan utama seorang pasien datang memeriksakan dirinya ke tenaga medis adalah karena sipasien mengalami masalah kesehatan (sakit) ataukah karena ingin memeriksakan kondisi kesehatannya (check up). Tentu saja factor motivasi kedua unsur diatas sangatlah berbeda. Perhatikan tabel dibawah ini :

Tabel 7

Alasan Utama Datang Ke Rumah Sakit/Tenaga Medis

\begin{tabular}{|c|l|r|r|}
\hline No & \multicolumn{1}{|c|}{ Alasan ke Rumah Sakit/Tenaga Medis } & F & $\%$ \\
\hline 1. & Karena sakit & 40 & 100 \\
2. & Memeriksa kondisi kesehatan (check up) & 0 & 0 \\
\hline \multicolumn{2}{|l|}{ Jumlah } & 40 & 100 \\
\hline
\end{tabular}

Sumber : Diolah dari Angket Agustus 2009

Berdasarkan data diatas maka 40 orang $(100 \%)$ responden mengatakan datang berobat ketenaga medis karena sakit, kalau alasan utamanya adalah karena sakit, itu berarti sipasiennya tidak sukarela untuk datang berobat tetapi karena terpaksa, berhubung karena kondisi kesehatannya terganggu, sehingga sipasien berada dalam posisi sangat memerlukan bantuan tenaga medis untuk mengatasi masalah kesehatannya. Posisi tawar pasien jelas berada pada posisi yang lemah di hadapan tenaga medis, apalagi di samping sebagai pasien Kusta, status ekonomi dari 40 orang responden juga adalah orang miskin, dimana pasien tidak mungkin mampu memilih-milih tenaga medis sesuai dengan seleranya, karena tidak akan sanggup membayar jasanya.

\section{Pemberian Persetujuan Oleh Pasien Terhadap Tindakan Medik Yang Dilakukan Tenaga Medis}

Pada waktu pasien datang berobat ke Rumah Sakit dan kemudian diperiksa oleh tenaga medis maka terjadilah hubungan antara tenaga medis dengan pasien. Untuk terjadinya hubungan antara tenaga medis dan pasien haruslah ada persetujuan dari pasien/keluarganya untuk dilakukan tindakan medik terhadap dirinya. Baik itu berupa tindakan pencegahan penyakit (preventif), pemeriksaan untuk menegakkan diagnosa (diagnostik), pengobatan (terapeutik) dan pemulihan kesehatan (rehabilitatif). Apakah pasien/keluarganya di Rumah Sakit Dr. Tadjuddin Chalid Makassar telah memberikan persetujuan ?. Perhatikan tabel dibawah ini : 
Tabel 8

Persetujuan Pasien/Keluarga untuk Dilakukan Pemeriksaan dan Pemberian Tindakan Medik yang Tidak Beresiko Tinggi Kepada Pasien

\begin{tabular}{|c|l|r|r|}
\hline No & \multicolumn{1}{|c|}{ Pemberian persetujuan oleh } & F & $\%$ \\
\hline 1. & Pasien & 40 & 100 \\
2. & Keluarga & 0 & 0 \\
3. & Pasien/keluarga tidak setuju & 0 & 0 \\
\hline \multicolumn{2}{|c|}{ Jumlah } & 40 & 100 \\
\hline
\end{tabular}

Sumber : Diolah dari Angket Agustus 2009

Tabel 9

Permintaan Persetujuan Oleh Tenaga Medis Untuk Melakukan Pemeriksaan

\begin{tabular}{|c|l|c|c|}
\hline No & \multicolumn{1}{|c|}{$\begin{array}{c}\text { Tenaga medis meminta persetujuan } \\
\text { pada saat melakukan pemeriksaan }\end{array}$} & F & $\%$ \\
\hline 1. & Ya & 18 & 45 \\
2. & Tidak & 22 & 55 \\
\hline \multicolumn{2}{|c|}{ Jumlah } & 40 & 100 \\
\hline
\end{tabular}

Sumber : Diolah dari Angket Agustus 2009

Tabel 8 diatas memperlihatkan bahwa semua (40 orang atau $100 \%$ ) responden (pasien) secara langsung tanpa diwakili keluarganya memberikan persetujuannya pada saat tenaga medis memeriksa tekanan darahnya, pemeriksaan fisik lainnya, pemeriksaan laboratorium, pemeriksaan foto dan lain-lain yang dilakukan oleh tenaga medis yang masuk kategori tindakan medik yang tidak beresiko tinggi atau bukan tindakan pembedahan. Sayangnya ada 22 orang (55\%) responden menyatakan bahwa tenaga medis tidak meminta persetujuan pada saat akan melakukan tindakan tersebut diatas (tabel 9), tetapi langsung saja melakukan pemeriksaan fisik, memberikan pengantar untuk pemeriksaan laboratorium/rontgen dsbnya dan hanya 18 orang (45\%) saja responden yang menyatakan bahwa tenaga medis meminta persetujuan darinya.

Ini mengindikasikan kalau tenaga medis belum memahami betul salah satu kewajibannya dalam informed consent yaitu meminta persetujuan dari pasien apabila ingin melakukan tindakan medik. Hal ini ditambah lagi dengan kurangnya tenaga medis yang memberikan penjelasan terhadap hal-hal yang berhubungan dengan pemeriksaan yang dilakukan, sehingga kadang membingungkan bagi 
pasien terhadap tujuan semua pemeriksaan yang dilakukan tenaga medis terhadap dirinya. Simak tabel dibawah ini :

Tabel 10

Penjelasan Tenaga Medis Terhadap Tujuan dan Hal-Hal yang Berhubungan dengan Pemeriksaan yang Dilakukan

\begin{tabular}{|c|l|c|c|}
\hline No & \multicolumn{1}{|c|}{ Tenaga medis memberikan penjelasan } & $\mathrm{F}$ & $\%$ \\
\hline 1. & Ya & 6 & 15 \\
2. & Tidak & 34 & 85 \\
\hline \multicolumn{2}{|c|}{ Jumlah } & 40 & 100 \\
\hline
\end{tabular}

Sumber : Diolah dari Angket Agustus 2009

Data di atas dengan gamblang membeberkan kalau mayoritas responden (34 orang atau $85 \%$ ) menyatakan bahwa tenaga medis dalam melakukan tindakan medis tidak memberikan penjelasan terhadap tujuan atau hal-hal yang berhubungan dengan pemeriksaan yang dilakukannya. Hal ini sudah pasti merugikan bagi pasien karena tidak mendapatkan informasi yang memadai tentang pengobatan atau tindakan medik yang akan dilakukan padanya. Sehingga bisa saja mengakibatkan kecacatan atau bahkan kematian dipihak pasien. Hanya sebagian kecil saja (6 orang atau $15 \%$ ) yang mengakui mendapatkan penjelasan yang memadai dari tenaga medis.

Menjawab hal tersebut, di atas maka menurut Dr. Aditia Akram, Kepala Bidang Medis Rumah Sakit Dr. Tadjuddin Chalid Makassar (wawancara, 6 Oktober 2009) bahwa :

Pada waktu pasien datang berobat ke tenaga medis, sudah ada keputusan dalam diri pasien untuk menyerahkan sepenuhnya pengobatan dirinya kepada tenaga medis, karena menganggap tindakan tenaga medis adalah tindakan yang terbaik bagi diri pasien atau dengan kata lain pasien sudah menyetujui tindakan yang akan dilakukan oleh tenaga medis, disamping itu karena tingkat pengetahuan (pendidikan) pasien kusta yang awam terhadap tindakan/pemeriksaan yang akan dilakukan oleh tenaga medis sehingga walaupun dijelaskan, pasien juga kurang atau tidak memahami penjelasan dari tenaga medis tentang hal-hal yang berhubungan dengan tindakan medik yang akan dilakukan, tetapi walaupun demikian tenaga medis tetap memberitahukan kepada pasien bahwa mereka akan diberikan pengantar untuk pemeriksaan laboratorium, rontgen dan sebagainya.

Peraturan perundang-undangan telah mengatur dengan jelas bahwa, kewajiban utama tenaga medis di dalam informed consent adalah meminta persetujuan dan memberikan penjelasan terhadap hal-hal yang berhubungan dengan tindakan medik yang akan dilakukan. Hal ini menandakan bahwa tenaga 
medis belum melakukan kewajibannya dengan baik. Sedangkan pada saat tenaga medis memberikan obat makan (oral), zalep, dan obat lainnya selain obat suntik, perhatikan tabel berikut :

Tabel 11

Penjelasan Tenaga Medis Terhadap Jenis Obat, Kegunaan, Cara Pemakaian dan Reaksi Setelah Pemakaian

\begin{tabular}{|c|l|c|c|}
\hline No & \multicolumn{1}{|c|}{ Tenaga medis memberikan penjelasan } & F & $\%$ \\
\hline 1. & Ya & 15 & 37,5 \\
2. & Tidak & 22 & 55 \\
3. & Dijelaskan tetapi tidak lengkap & 3 & 7,5 \\
\hline \multicolumn{2}{|c|}{ Jumlah } & 40 & 100 \\
\hline
\end{tabular}

Sumber : diolah dari Angket Agustus 2009

Dari data di atas dapat dilihat bahwa 22 orang (55\%) responden menyatakan tidak mendapatkan penjelasan dari tenaga medis, 3 orang $\quad(7,5 \%)$ mengaku dijelaskan tetapi tidak lengkap atau mendapatkan penjelasan tetapi hanya sebagian dan cuma 15 orang $(37,5)$ saja yang mengaku mendapatkan penjelasan yang lengkap dari tenaga medis tentang jenis obatnya, kegunaannya, cara pemakaiannya serta reaksi-reaksi yang mungkin timbul setelah pemakaian obat tersebut.

Selain itu, dari 40 orang responden yang di bagikan angket, sebanyak 29 orang mengaku pernah mendapatkan obat suntik dari tenaga medis, dan dari 29 orang $(100 \%)$ responden itu, semuanya mengungkapkan setuju diberikan obat suntikan, hanya saja sebagian besar responden mengungkapkan tenaga medis tidak memberikan mereka penjelasan yang memadai tentang jenis obat yang diberikan, kegunaannya, dan reaksi yang mungkin timbul setelah diberikannya suntikan itu. Lihat tabel berikut :

Tabel 12

Penjelasan Tenaga Medis Terhadap Jenis Obat suntikan, Kegunaan, dan Reaksi Obat Setelah Penyuntikan

\begin{tabular}{|c|l|c|c|}
\hline No & \multicolumn{1}{|c|}{ Tenaga medis memberikan penjelasan } & $\mathrm{F}$ & $\%$ \\
\hline 1. & Ya & 11 & 37,9 \\
2. & Tidak & 17 & 58,7 \\
3. & Dijelaskan tetapi tidak lengkap & 1 & 3,4 \\
4. & Tidak mendapat obat suntik & 11 & 0 \\
\hline \multicolumn{2}{|l|}{ Jumlah } & 40 & 100 \\
\hline
\end{tabular}

Sumber : Diolah dari Angket Agustus 2009 
Tabel diatas memperlihatkan bahwa 17 orang $(58,7 \%)$ responden mengatakan tidak mendapatkan penjelasan dari tenaga medis, 1 orang $\quad(3,4 \%)$ mengungkapkan diberikan penjelasan tetapi tidak lengkap atau diberikan penjelasan tetapi hanya sebagian dan 11 orang $(37,9 \%)$ sajalah yang menyatakan tenaga medis memberikan mereka penjelasan yang memadai tentang jenis obat suntikan yang diberikan, kegunaannya, dan reaksi yang mungkin timbul setelah diberikannya suntikan itu.

Menyikapi hal tersebut di atas, maka menurut Dr. Aditia Akram Kepala Bidang Medis Rumah Sakit Dr. Tadjuddin Chalid Makassar (wawancara, 6 Oktober 2009) mengatakan :

Penjelasan tenaga medis terhadap pemberian obat oral, zalf maupun suntikan kepada pasien kadang terlupakan, karena terlalu banyaknya pasien yang dilayani, kekurang-tahuan sebagian tenaga medis untuk memberikan penjelasan, disamping itu karena tipe pasien kusta adalah pasien penyakit kronis sehingga memerlukan/mendapatkan pengobatan yang berulang dengan obat yang sama, hal ini menyebabkan tenaga medis pada saat memberi obat (oral,zalf atau suntikan) tidak memberikan penjelasan lagi karena menganggap pasien sudah mengetahui tentang halhal yang berhubungan dengan pengobatan yang dilakukan terhadap dirinya, tetapi memang pelayanan tenaga medis dan sistem kerja yang berlangsung harus tetap mendapatkan perbaikan demi memberikan pelayanan yang terbaik kepada pasien.

Ini menegaskan bahwa tenaga medis belumlah sepenuhnya menyadari tanggung jawabnya untuk memberikan penjelasan kepada pasien pada saat akan memberikan obat oral, zalf atau suntikan (tindakan medik) kepada pasien, padahal pemberian obat kepada pasien mempunyai resiko yang bisa menyebabkan alergi, kecacatan bahkan sampai kepada kematian pada pasien apabila terjadi kesalahan/kelalaian dalam pemberian obat. Hal ini jelas bisa saja merugikan pasien, disamping itu juga, sudah menjadi hak pasien untuk mendapatkan penjelasan dari tenaga medis tentang hal-hal yang berhubungan dengan tindakan yang akan dilakukan kepadanya.

\section{Proses Pemberian Persetujuan Tindakan Medik Pembedahan Oleh Pasien}

Dari 40 orang responden yang di berikan angket oleh penulis, sebanyak 22 orang (55\%) yang mengaku pernah mengalami tindakan pembedahan (operasi) dan 18 orang (45\%) yang menyatakan tidak pernah di bedah (operasi). Sebelum dilakukannya tindakan pembedahan oleh tenaga medis, penjelasan yang lengkap tentang penyakitnya, tindakan bedah yang akan dilakukan, risikonya, cara pembedahannya, harapan sembuhnya dll, wajib diberikan oleh tenaga medis 
kepada pasien atau keluarga terdekatnya. Apalagi tindakan pembedahan adalah termasuk tindakan medik yang berisiko tinggi terjadinya kematian atau kecacatan pada pasien. Apakah sebelum melakukan pembedahan, tenaga medis di Rumah Sakit Dr. Tadjuddin Chalid Makassar telah memberikan penjelasan ?. Untuk lebih jelasnya simak tabel berikut :

Tabel 13

Penjelasan Tenaga Medis Terhadap Hal-hal yang Berhubungan dengan Tindakan Pembedahan yang Akan Dilakukan

\begin{tabular}{|c|l|c|c|}
\hline No & \multicolumn{1}{|c|}{ Tenaga medis memberikan penjelasan } & F & $\%$ \\
\hline 1. & Ya & 16 & 72,7 \\
2. & Tidak & 1 & 4,6 \\
3. & Dijelaskan tetapi tidak lengkap & 5 & 22,7 \\
4. & Tidak pernah di bedah (operasi) & 18 & 0 \\
\hline \multicolumn{2}{|c|}{ Jumlah } & 40 & 100 \\
\hline
\end{tabular}

Sumber : Di olah dari Angket Agustus 2009

Berdasarkan data di atas, ada 16 orang $(72,7 \%)$ responden yang mengaku mendapatkan penjelasan yang lengkap tentang penyakitnya, tindakan bedah yang akan dilakukan, risikonya, cara pembedahannya, harapan sembuhnya dll, 5 orang $(22,7 \%)$ menyatakan mendapatkan penjelasan tetapi hanya memahami sebagian penjelasan dari tenaga medis alias penjelasannya tidak lengkap, dan adapula 1 orang $(4,6 \%)$ yang mengungkapkan tidak mendapatkan penjelasan samasekali dari tenaga medis. Menanggapi temuan di atas maka menurut Dr. Ilyas Rahim, dokter senior di Rumah Sakit Dr. Tadjuddin Chalid Makassar (wawancara, 5 Oktober 2009), menyatakan :

Tindakan pembedahan yang dilakukan kepada pasien seharusnya dijelaskan, tetapi pasien susah untuk memahami disebabkan karena tingkat pendidikan yang kurang, sehingga komunikasinya tidak nyambung, disamping itu mereka sudah pasrah dan menyerahkan sepenuhnya kepada dokter (tenaga medis).

Sebagai sebuah tindakan medik yang mempunyai risiko tinggi yang bisa menyebabkan kecacatan atau kematian tindakan pembedahan haruslah dipertimbangkan dengan matang oleh tenaga medis sebelum melaksanakan tindakan tersebut. Permintaan persetujuan dan penjelasan yang sejelas-jelasnya tentang tindakan pembedahan dan hal-hal yang berhubungan dengannya wajib dilakukan tenaga medis. Hal ini disebabkan karena pihak pasien berpotensi melaporkan atau melakukan gugatan kepengadilan apabila terjadi hal-hal yang merugikan bagi pasien. Oleh sebab itu persetujuan secara tertulis sebaiknya 
diminta oleh tenaga medis kepada pasien atau keluarganya apabila ingin melakukan tindakan pembedahan. Persetujuan pasien atau keluarganya tersebut dapat dijadikan bukti yang kuat dipengadilan nanti apabila terjadi gugatan dari pihak pasien.

Untuk mendapatkan gambaran lebih jelas tentang penandatanganan formulir persetujuan tindakan pembedahan oleh pasien, dapat kita lihat pada tabel di bawah ini :

Tabel 14

Penanda tanganan Izin Tindakan Pembedahan

\begin{tabular}{|c|l|c|c|}
\hline No & \multicolumn{1}{|c|}{ Menandatangani izin pembedahan } & F & $\%$ \\
\hline 1. & Ya & 19 & 86,4 \\
2. & Tidak & 3 & 13,6 \\
3. & Tidak pernah di bedah (operasi) & 18 & 0 \\
\hline \multicolumn{2}{|c|}{ Jumlah } & 40 & 100 \\
\hline
\end{tabular}

Sumber : Diolah dari Angket Agustus 2009

Data diatas memperlihatkan dari 22 orang responden yang mengaku pernah di bedah (operasi), 19 orang $(86,4 \%)$ responden menyatakan menandatangani persetujuan (izin) pembedahan dan masih ada juga 3 orang $(13,6 \%)$ responden mengatakan dia dan atau keluarga terdekatnya tidak pernah diminta oleh tenaga medis atau petugas kesehatan lainnya untuk menanda tangani formulir persetujuan (izin) tindakan pembedahan. Menurut Dr. Ilyas Rahim, dokter senior di Rumah Sakit Dr. Tadjuddin Chalid Makassar (wawancara, 5 Oktober 2009), bahwa :

Adanya pasien yang tidak menandatangani izin pembedahan adalah merupakan kelalaian dari petugas, walaupun tidak menandatangani izin (formulir), tetapi secara lisan mereka sudah menyetujui tindakan bedah yang akan dilakukan, disamping itu karena mereka sebagian besar adalah pasien yang akan menjalani pembedahan lanjutan (berkesinambungan), sehingga penandatanganan izin pada pembedahan yang kedua dan seterusnya tidak di persoalkan lagi, mereka sudah dianggap menyetujui tindakan pembedahan.

Tindakan ceroboh ini bisa saja merugikan sitenaga medis yang melakukan pembedahan, karena siapa tahu sipasien yang di berikan tindakan pembedahan mengalami kerugian sehingga melakukan gugatan, dan kemudian di pengadilan dia atau keluarga terdekatnya tidak mengakui bahwa pernah menyetujui/menandatangani persetujuan (izin) tindakan pembedahan, maka kemungkinan besar pihak sipasien tersebut yang dimenangkan oleh hakim dalam 
perkara itu. Padahal didalam pasal 45 ayat (5) Undang-Undang no 29 tahun 2004 tentang Praktik Kedokteran jo PerMenKes no 290 tahun 2008 pasal 3 ayat (1) menyatakan :

Setiap tindakan kedokteran atau kedokteran gigi yang mengandung risiko tinggi harus diberikan dengan persetujuan tertulis yang ditandatangani yang berhak memberikan persetujuan.

Berdasarkan tabel 13 dan 14 di atas, walaupun ada 1 orang (4,6 \%) responden yang mengaku tidak diberikan penjelasan tentang hal-hal yang berhubungan dengan tindakan pembedahan yang akan dilakukan tenaga medis terhadapnya, 5 orang $(22,7 \%)$ yang menyatakan diberi penjelasan tetapi tidak lengkap, disamping itu ada 3 orang $(13,6 \%)$ yang tidak menandatangani formulir izin persetujuan tindakan pembedahan, tetapi semua responden yang mengungkapkan pernah menjalani tindakan pembedahan, menyatakan setuju dilakukannya tindakan pembedahan oleh tenaga medis terhadapnya. Ini menandakan bahwa hubungan paternalistik antara tenaga medis dan pasien di dalam realitasnya di Rumah Sakit Dr. Tadjuddin Chalid Makassar masih sangat kental. Sikap ini beranggapan bahwa hubungan antara tenaga medis dengan pasien bagaikan hubungan antara bapak dengan anaknya. Yang dipilihkan atau yang dilakukan oleh bapak pasti yang terbaik untuk anaknya, atau dengan kata lain pasien masih bersikap pasrah saja. Apa yang dikatakan atau dianjurkan oleh tenaga medisnya diterima dan dituruti saja semuanya oleh pasien. Hal ini dibenarkan oleh Nurhayati salah seorang pasien rawat nginap di Rumah Sakit Dr Tadjuddin Chalid Makassar (wawancara, 8 Agustus 2009) sebagai berikut :

Pasien menyerahkan sepenuhnya atau menerima sepenuhnya pengobatan dari dokter karena hal itu juga untuk kebaikan atau kesembuhan bagi pasien sendiri.

Kepercayaan kepada tenaga medis yang sangat besar juga terlihat pada kehadiran saksi saat penandatanganan persetujuan (izin) pembedahan, lebih jelasnya perhatikan tabel berikut :

Tabel 15

Saksi pada Penandatanganan Izin Pembedahan

\begin{tabular}{|c|l|c|c|}
\hline No & \multicolumn{1}{|c|}{ Ada tandatangan saksi } & F & $\%$ \\
\hline 1. & Ya & 16 & 84,2 \\
2. & Tidak & 3 & 15,8 \\
3. & Tidak menandatangani izin pembedahan & 3 & 0 \\
4. & Tidak pernah di bedah (operasi) & 18 & 0 \\
\hline \multicolumn{2}{|c|}{ Jumlah } & 40 & 100 \\
\hline
\end{tabular}

Sumber : Diolah dari Angket Agustus 2009 
Data di atas memperlihatkan dari 19 orang pasien yang mengaku menandatangani persetujuan (izin) pembedahan, 16 orang $(84,2 \%)$ menyatakan tidak mempunyai saksi dari pihaknya, dan hanya 3 orang (15\%) yang mengemukakan mempunyai saksi, itupun juga tidak memenuhi syarat-syarat memberikan kesaksian, karena yang menjadi saksi adalah istri/suami dan anak kandung dari pasien.

\section{PENUTUP}

\section{Kesimpulan}

Setelah diuraikan bagian demi bagian penulis mencoba menarik beberapa kesimpulan sebagai berikut :

a. Pemahaman tenaga medis (dokter umum dan dokter gigi umum) di Rumah Sakit Dr. Tadjuddin Chalid tentang informed consent masih perlu ditingkatkan karena semua tenaga medis yang dijadikan responden belum memahami dengan baik informed consent tersebut, hal ini terlihat pada pemahaman tentang unsur terpenting di dalam informed consent, siapa yang bertanggung jawab dalam pemberian informasi tentang tindakan medik, perlunya persetujuan pada saat akan melakukan pemeriksaan awal dan pemberian obat, penjelasan terhadap penyakit pasien dan hal-hal yang berhubungan dengan itu, serta pada apa sajakah dibutuhkan informed consent yang tertulis.

b. Pelaksanaan informed consent yang sesuai dengan peraturan perundang-undang yang berlaku (Pasal 45 Undang-undang no 29 tahun 2004 tentang Praktik Kedokteran jo PerMenKes no 290 tahun 2008 tentang Persetujuan Tindakan Kedokteran) di Rumah Sakit Dr. Tadjuddin Chalid Makassar belumlah terlaksana dengan baik, hal ini disebabkan karena sebagian tenaga medis belum melaksanakan isi peraturan perundang-undangan tersebut.

\section{Saran}

Perlu diadakan diskusi dengan para tenaga medis (dokter umum dan dokter gigi umum) sebagai pemberi pelayanan kesehatan (medical providers) di Rumah Sakit Dr. Tadjuddin Chalid Makassar di dalam menyatukan perbedaan persepsi tentang informed consent sesuai dengan peraturan perundang-undangan yang berlaku. Dalam rangka mencerdaskan pasien, perlu adanya penyuluhan kepada pasien tentang hal-hal yang berhubungan dengan informed consent di dalam posisinya sebagai penerima pelayanan pelayanan kesehatan ( medical receivers) dari tenaga medis di Rumah Sakit Dr. Tadjuddin Chalid Makassar. 


\section{DAFTAR PUSTAKA}

Adami Chazawi, 2007, Malpraktik Kedokteran, Bayumedia Publishing, Malang.

Bahder J.N, 2005, Hukum Kesehatan Pertanggungjawaban Dokter, Rineka Cipta, Jakarta.

Chrisdiono M.A, 2007, Dinamika Etika \& Hukum Kedokteran dalam Tantangan Zaman, EGC, Jakarta.

Dinajani S.A.M, 2008, Qua Vadis Kliniko Mediko Legal Indonesia, Fakultas Kedokteran Universitas Indonesia, Jakarta.

Hendrojono Soewono, 2007, Batas Pertanggungjawaban Hukum Malpraktik Dokter Dalam Transaksi Terapeutik, Srikandi, Surabaya.

I Nyoman Agus W.P, 2003, Perlindungan Hukum Terhadap Pasien Sebagai Konsumen Jasa di Bidang Pelayanan Medis (Suatu Tinjauan Dari Sudut Hukum Perdata), (online), ( @ indoskripsi.com.website hosting by Ide Bagus, di akses 28 Pebruari 2009).

J. Guwandi, 2004, Informed Consent, Fakultas Kedokteran Universitas Indonesia, Jakarta.

2005, Rahasia Medis, Fakultas Kedokteran Universitas Indonesia, Jakarta.

M. Jusuf Hanafiah dan Amri Amir, 1999, Etika Kedokteran \& Hukum Kesehatan, EGC, Jakarta.

Muh. Syahid Husain, 2008, Aspek Hukum Perjanjian Kredit Pemilikan Kendaraan Bermotor pada Perusahaan Pembiayaan, Skripsi tidak diterbitkan Fakultas Hukum Universitas 45, Makassar. 
Muljadi, Kartini dan Widjaja Gunawan, 2002, Perikatan Yang Lahir dari Perjanjian, Raja Grafindo, Jakarta.

Rival Ahmad, Dkk, 2006, Panduan Bantuan Hukum di Indonesia, Sentralisme Production, Jakarta.

Subekti, 2002, Hukum Perjanjian, Intermasa, Jakarta. 